\title{
Mangiferin and mangiferin-containing leaf extract from Mangifera foetida $L$ for therapeutic attenuation of experimentally induced iron overload in a rat model
}

\author{
Ari Estuningtyas $^{1+1}$, Tri Wahyuni ${ }^{2}$, Pustika Amalia Wahidiyat ${ }^{3}$, Ernie H Poerwaningsih ${ }^{4}$, Hans-Joachim Freisleben $^{5}$ \\ ${ }^{1}$ Department of Pharmacology, Faculty of Medicine, Universitas Indonesia, Jakarta, Indonesia \\ ${ }^{2}$ Pharmacology Division, Faculty of Pharmaceutical, Universitas Indonesia, Depok, Indonesia \\ ${ }^{3}$ Department of Pediatrics, Faculty of Medicine, Universitas Indonesia-Cipto Mangunkusumo Hospital, Jakarta, Indonesia \\ ${ }^{4}$ Department of Pharmacy, Faculty of Medicine, Universitas Indonesia, Jakarta, Indonesia \\ ${ }^{5}$ Medical Research Unit, Faculty of Medicine, Universitas Indonesia, Jakarta, Indonesia
}

\section{A R T I C L E I N F O}

Article Type:

Original Article

\section{Article History:}

Received: 7 November 2018

Accepted: 5 December 2018

Keywords:

Thalassemia

Mangiferin

Mangifera foetida

Medicinal plant

Iron overload

Iron chelation

Iron excretion

\begin{abstract}
A B S T RAC T
Introduction: Thalassemia is a hereditary anemia usually treated with regular blood transfusions, which can result in elevated levels of total iron in the body. As soon as the capacity of iron-regulating proteins (e.g., ferritin, transferrin) are used up, free plasma iron increases generating reactive oxygen species (ROS), leading to oxidative stress. Hence, blood transfusions should be accompanied by iron-chelating therapy, e.g., deferiprone (DFP). The purpose of this study was to evaluate the effect of mangiferin (M) and an aqueous leaf extract of Mangifera foetida L (EMF) as alternative iron-chelating antioxidants in an animal model. Methods: Thirty male Sprague Dawley rats were randomly divided into 5 equal groups: normal control, iron overload (IO), IO+DFP, IO+M, and IO+EMF. Iron overload was induced by intraperitoneal iron dextran injection with a total dose of $90 \mathrm{mg} /$ mouse $(15 \mathrm{mg} \mathrm{Fe} /$ mouse every 3-4 days for 3 weeks) followed by oral administration of DFP $462.5 \mathrm{mg} / \mathrm{kg}$, mangiferin $75 \mathrm{mg} / \mathrm{kg}$, or EMF $2.930 \mathrm{~g} / \mathrm{kg}$ for 7 days.

Results: Body weight (BW) increased in all groups during the 4 weeks of experiment, except for the IO group. As expected, DFP decreased significantly the total plasma iron and increased iron excretion via urine in iron-overloaded rats (positive control), mangiferin and EMF had similar - although slightly smaller - effects than DFP. The antioxidant activity of $M$ and EMF were stronger compared to DFP as determined by plasma superoxide dismutase (SOD) activity.

Conclusion: Mangiferin and EMF have iron-chelating and antioxidant effects and might be used for the treatment of iron overload in the body.
\end{abstract}

Implication for health policy/practice/research/medical education:

Mangiferin and mangiferin-containing extracts from Mangifera foedita leaves are potent candidates as antioxidant iron chelators in the management of iron-overloaded thalassemia patients and may help to lower the costs of their treatment.

Please cite this paper as: Estuningtyas A, Wahyuni T, Wahidiyat PA, Poerwaningsih EH, Freisleben HJ. Mangiferin and mangiferin-containing leaf extract from Mangifera foetida $\mathrm{L}$ for therapeutic attenuation of experimentally induced iron overload in a rat mode. J Herbmed Pharmacol. 2018;9(1):21-27. doi: 10.15171/jhp.2019.04.

\section{Introduction}

Thalassemia is a hereditary hemolytic anemia resulting from the pathological synthesis of abnormal hemoglobin (1). The disease spreads from the Mediterranean via the Middle East and India to South-East Asia (2). In Indonesia, thalassemia is the most frequent single genetic disorder and a serious health problem due to the high morbidity and mortality of patients. The frequence of $\beta$-thalassemia gene and $\mathrm{HbE}$ in Indonesian carriers ranges between $1 \%-33 \%$ (2). Clinically, thalassemia is divided into minor (or trait), intermedia and major ones $(1,3)$. The clinical pictures of chronic anemia because erythropoiesis does not function well, intra- and extramedullary hemolysis occurs, and iron overload is present due to increased gastro-intestinal (GI) iron absorption and supply of blood transfusions (4). 
Iron overload is a long-term condition in which the body absorbs excessive amounts of iron into the blood from which it accumulates in body tissues, such as liver, heart and other organs (5). Iron overload can be dangerous as a progressive cause of irreversible organ damage before clinical symptoms develop $(6,7)$.

Free iron can generate reactive oxygen species (ROS), which cause damage to tissues, especially to the liver and the heart (8-10). Excess iron in the body must be treated with iron chelators $(11,12)$, e.g., deferoxamin (DFO) as one of the standard drugs. Besides the high price, DFO has serious side effects and a complicated invasive method of administration. Oral chelating agents have been developed and released to the market, such as deferiprone (DFP) and deferasirox, but the application of these drugs is still very limited because of their high price. Until now, the goal of treatment of iron overload due to repeated transfusions in patients with thalassemia can often not be reached because of price constraints.

During the last years, researches have been conducted for the development of alternative iron-chelating agents from natural sources in Indonesia, which are safer, less expensive, and readily available to Indonesian patients (13). One of these herbal candidates is mangiferin, a flavonoid extracted from various parts of Mangifera indica L., which was proven an antioxidant and iron chelator in vitro (14-17). The formula of mangiferin was presented by Pardo-Andreau et al (14).

Soediro et al (18) found that among seven mango cultivars in Indonesia, the leaves of $M$. foetida $\mathrm{L}$ had the highest content in mangiferin. Purwaningsih et al (19) reported in an ex vivo study that $1.125 \mathrm{mg}$ aqueous leaf extract of $M$. foetida had no significantly different ironchelating effect compared to 100 ug of purified mangiferin.

This research was carried out with mangiferincontaining aqueous leaf extract from M. foetida as iron chelation therapy and compared with DFP as the standard drug. Our model used mice, which was administered excessive iron resulting in experimental iron overload. The results are expected to be useful as iron chelation in patients with thalassemia for complementary and/or alternative therapy. The research data can also be used for testing the effectiveness and safety in the next phase or even in clinical trials.

\section{Materials and Methods}

Mangiferin and leaf extract from Mangifera foetida $\mathrm{L}$ Purified mangiferin (content 95.8\%) was obtained from extracts of leaves of Mangifera indica L (Plamed Science Technology Inc., China). Leaf extract from M. foetida (EMF) was prepared according to Wayuni et al (20). Leaves from $M$. foetida (Indonesian name Mangga bacang) from the Depok area, West Java, were identified by LIPI Kebun Raya Bogor (Botanical Garden Bogor, certificate 4565/ IPH.3/KS/X/2014).

Chemical analysis of the ethanolic EMF by Wayuni et al (20) showed no alkaloids (= negative Mayer-BouchardatDragendorf reactions), but presence of flavonoids and saponins (strong positive chemical reactions), as well as triterpenoids (positive Liebermann-Burchard reaction). Total flavonoid content was $1.035 \%$ (w/w); mangiferin was identified as the major flavonoid in the extract by thin layer chromatography (TLC) with mobile phase methanolacetate-water (9:0.5:0.5). TLC demonstrated a mangiferin spot in the extract at the same $\mathrm{Rf}$ and with the same reaction as pure mangiferin ( $\mathrm{Rf} 0.86$ ). Semiquantitative TLC determination confirmed the mangiferin content in the leaf extract of about $1 \%(20)$.

Experimental animals and study design

Thirty male Sprague Dawley rats were randomly divided into 5 equal groups: normal group $(\mathrm{N})$, the group of iron overload without therapy as negative control (IO), the group of iron overload that received DFP as the positive control $(\mathrm{IO}+\mathrm{DFP})$, mangiferin $75 \mathrm{mg} / \mathrm{kg}(\mathrm{IO}+\mathrm{M})$, and $\mathrm{EMF}(\mathrm{IO}+\mathrm{EMF})$. Induction of iron overload was achieved by intraperitoneal (IP) injection of $0.3 \mathrm{~mL}$ iron dextran containing $15 \mathrm{mg} \mathrm{Fe}$, twice a week for 3 weeks. After 3 weeks of iron overloading, therapy followed orally for 7 days (week 4) with DFP, mangiferin, or EMF, respectively (Table 1).

Blood was taken from the orbital sinus 3 times during

Table 1. Study design: treatment of animals

\begin{tabular}{|c|c|c|c|c|c|c|c|c|c|c|c|c|c|c|c|}
\hline \multirow{2}{*}{ Groups } & \multicolumn{7}{|c|}{ Weeks 1,2 , and 3} & \multicolumn{7}{|c|}{ Week 4} & \multirow{2}{*}{$\begin{array}{c}\begin{array}{c}\text { Sacrificed after } 4 \\
\text { weeks }\end{array} \\
\end{array}$} \\
\hline & Day 1 & Day 2 & Day 3 & Day 4 & Day 5 & Day 6 & Day 7 & Day 1 & Day 2 & Day 3 & Day 4 & Day 5 & Day 6 & Day 7 & \\
\hline$N=C$ & - & - & - & - & - & - & - & - & - & - & - & - & - & - & $x$ \\
\hline 10 & $\bullet$ & - & - & $\bullet$ & - & - & - & - & - & - & - & - & - & - & $x$ \\
\hline IO+DFP & - & - & - & $\bullet$ & - & - & - & 0 & 0 & 0 & $\diamond$ & 0 & 0 & 0 & $\mathrm{x}$ \\
\hline $10+M$ & $\bullet$ & - & - & $\bullet$ & - & - & - & $\square$ & $\square$ & $\square$ & $\square$ & $\square$ & $\square$ & $\square$ & $x$ \\
\hline IO+EMF & • & - & - & - & - & - & - & $*$ & $*$ & * & * & * & * & * & $x$ \\
\hline
\end{tabular}

Note: $\mathrm{N}=$ normal control; IO= iron overload $90 \mathrm{mg} \mathrm{IP/} \mathrm{kg} \mathrm{BW} \mathrm{(negative} \mathrm{control);} \mathrm{IO+DFP} \mathrm{=} \mathrm{iron} \mathrm{overload} \mathrm{+} \mathrm{deferiprone} 75 \mathrm{mg} / \mathrm{kg}$ BW (positive control); $\mathrm{IO}+\mathrm{M}=$ iron overload + mangiferin $75 \mathrm{mg} / \mathrm{kg} \mathrm{BW}$; IO+EMF = iron overload + Mangifera foetida leaf extract $2930 \mathrm{mg} / \mathrm{kg}$ BWequivalent to mangiferin $75 \mathrm{mg} / \mathrm{kg} \mathrm{BW} ; \bullet=$ administration of iron dextran; $\diamond=$ administration of deferiprone; $\square=$ administration of mangiferin; $\boldsymbol{\star}=$ administration of Mangifera foetida leaf extract. 
the study, at the beginning of the study, after 3 weeks (induction of iron overload), and after therapy (week 4). Urine was collected twice, after 3 weeks and after therapy (week 4). Iron levels were determined from blood and urine, superoxide dismutase (SOD) activity and malondialdehyde (MDA) levels only from blood.

During the four weeks of the experiment, the rats were treated according to prevailing standards and monitored daily and noted signs of general toxicity such as weight loss, diarrhea and death. The animals were kept according to the Helsinki and Tokyo Declarations in their updated international version of year 2000 and European Directives for Animal Experiments (1986/609/EEC and 2010/63/EU).

Assay of total iron in plasma and urine

Measurement of the iron concentration in plasma and urine referred to publications by Rodríguez et al (17) and Papanasstosiou et al (21) with slight modifications based on preliminary tests conducted prior to the main study. Plasma samples $(100 \mu \mathrm{L})$ or urine $(300 \mu \mathrm{L})$ were destroyed with $1 \mathrm{~mL}$ conc. $\mathrm{HNO}_{3} / \mathrm{HClO}_{4}(2: 1)$ and then diluted with distilled water to a volume of $5 \mathrm{~mL}$. Subsequently, measurement was done with AAS in BGC-D2 lamp mode at a wavelength of $\lambda 248.3 \mathrm{~nm}$.

Determination of SOD activity in blood

SOD activity was determined according to the method Misra and Fridovich (22). Samples of blood homogenate of $250 \mathrm{~mL}$ to $400 \mathrm{~mL}$ of solution mixture was added chloroform-ethanol (3:5), then centrifuged at $3000 \mathrm{rpm}$ for 10 minutes. Light yellow filtrate taken $10 \mu \mathrm{L}$ clear then added $90 \mu \mathrm{L}$ aquabidest and $2775 \mu \mathrm{L}$ carbonate buffer $0.0518 \mathrm{M}$ and $125 \mu \mathrm{L}$ epinephrine solution $0.01 \mathrm{M}$.

The absorbance of this mixture was measured after 1, 2, 3 and 4 minutes at a wavelength of $480 \mathrm{~nm}$ and temperature of $37^{\circ} \mathrm{C}$. SOD activity in blood was calculated as inhibition of epinephrine oxidation, $50 \%$ inhibition being equivalent to $1 \mathrm{U}$ og SOD (or "SOD-like") activity.

\section{MDA determination with the TBA method}

Examination of lipid peroxidation by using MDA measurement was done according to the method of Wills modified by Devasagayam et al (23). To the samples or standards in the form of plasma MDA $200 \mu \mathrm{L}$ plus 1800 $\mu \mathrm{L}$ of distilled water, $1 \mathrm{~mL}$ TCA $20 \%$ and $2 \mathrm{~mL}$ TBA $0.67 \%$ were added and mixed homogeneously. The mixture was measured with a spectrophotometer at a wavelength of $530 \mathrm{~nm}$.

Data processing and statistical analysis

The results obtained in the form of numerical data comparing the results of more than two groups were statistically analyzed by one-way ANOVA parametric test for normal distribution and homogeneous variance. Limit of significance was set to $P=0.05$. To compare two groups, post hoc multiple comparison test LSD followed. If the above ANOVA hypothesis did not qualify, Kruskal-Wallis test followed by post hoc Mann-Whitney was applied.

\section{Results}

Body weight

Between the first and the 25th day, all groups gained weight $(28-51 \mathrm{~g})$, except for the iron-overloaded group (IO), which had a slight weight loss.

Plasma iron concentration

The difference in plasma iron between 3 and 4 weeks of the experimental course was calculated from the values in Table 2. In normal controls the difference in iron concentration was $+1.22 \pm 0.57 \mu \mathrm{g} / \mathrm{mL}$ (slight increase), in the IO group the difference in iron concentration was $-15.0814 .78 \mu \mathrm{g} / \mathrm{mL}$ (slight decrease), whereas the decrease was significant in all therapy groups: $261.92 \pm 183.20 \mu \mathrm{g}$ $\mathrm{Fe} / \mathrm{mL}$ in $\mathrm{IO}+\mathrm{DFP}, 217.08 \pm 198.79 \mu \mathrm{g} \mathrm{Fe} / \mathrm{mL}$ in $\mathrm{IO}+\mathrm{M}$, and $168.20 \pm 166.24 \mu \mathrm{g} \mathrm{Fe} / \mathrm{mL}$ in IO+EMF.

\section{Iron excretion via urine}

To evaluate the effect of the therapies, the differences of iron excretion in urine between 3 and 4 weeks of the experimental course were calculated from the values in Table 2. In normal controls, there was no difference. In the IO group, iron excretion increased by $2.83 \pm 1.64 \mu \mathrm{g} /$ $\mathrm{mL}$, in the IO+DFP group, iron excretion increased by $39.27 \pm 6.71 \mu \mathrm{g} / \mathrm{mL}$, in the $\mathrm{IO}+\mathrm{M}$ group by $12.30 \pm 5.48 \mu \mathrm{g} /$ $\mathrm{mL}$, and in the $\mathrm{IO}+\mathrm{EMF}$ group by $3.99 \pm 1.93 \mu \mathrm{g} / \mathrm{mL}$.

\section{MDA plasma concentration}

After 3 weeks, MDA was $0.908 \pm 0.23 \mathrm{nmol} / \mathrm{mL}$ in normal controls and increased significantly $(P=0.018)$ in all iron overloaded groups to a range between 4.17 and $5.71 \mathrm{nmol} /$ $\mathrm{mL}$ without significant differences between these groups $(\mathrm{p}=0.327)$. After 4 weeks and treatment of the IO+DFP, $\mathrm{IO}+\mathrm{M}$, and $\mathrm{IO}+\mathrm{EMF}$ groups, MDA was $0.726 \pm 0.16 \mathrm{nmol} /$ $\mathrm{mL}$ in normal controls and between 1.21 and $1.49 \mathrm{nmol} /$ $\mathrm{mL}$ in all iron-overloaded groups without any significant differences before and after treatments and between all groups (Figure 1).

Iron overload increased MDA significantly 4- to 5 -fold, which was the only significant result in MDA measurements. Treatment with iron-chelators decreased MDA generation, but the IO group without any therapeutic treatment exhibited the same effect. Differences between all these groups were not significant.

SOD activity in blood

SOD activity in plasma was measured as inhibition of epinephrine oxidation. We determined epinephrine oxidation in plasma after 3 weeks and after 4 weeks in our experimental design. Then, we calculated the difference in 
Table 2. Total Fe concentration in plasma and excretion in urine

\begin{tabular}{|c|c|c|c|c|c|c|}
\hline Parameter & $\begin{array}{l}\text { Normal } \\
\text { control (C) }\end{array}$ & $\begin{array}{l}10=\text { Iron } \\
\text { overload }\end{array}$ & $\begin{array}{l}\text { IO + DFP } \\
\text { (deferiprone) }\end{array}$ & $\begin{array}{l}10+M \\
\text { (mangiferin) }\end{array}$ & $\begin{array}{l}\text { IO + EMF (M. } f . \\
\text { leaf extract) }\end{array}$ & $\begin{array}{l}\text { Significance } \\
(P<0.05)\end{array}$ \\
\hline \multicolumn{7}{|l|}{ Body weight } \\
\hline Day 1 & $196.67 \pm 25.48$ & $235.67 \pm 14.11$ & $212.33 \pm 24.64$ & $220.33 \pm 23.34$ & $203.00 \pm 21.31$ & \multirow{2}{*}{ Not significant } \\
\hline Day 25 & $246.67 \pm 13.66$ & $229.00 \pm 40.37$ & $263.83 \pm 24.33$ & $268.33 \pm 21.13$ & $231.83 \pm 52.00$ & \\
\hline \multicolumn{7}{|c|}{ Total plasma iron concentration $(\mu \mathrm{g} / \mathrm{mL})$} \\
\hline $\begin{array}{l}\text { After } 3 \text { weeks = before } \\
\text { therapy }\end{array}$ & $1.46 \pm 0.56$ & $315.46 \pm 233.23$ & $371.49 \pm 253.62$ & $363.58 \pm 289.84$ & $317.65 \pm 280.73$ & \\
\hline $\begin{array}{l}\text { After } 4 \text { weeks = after } \\
\text { therapy }\end{array}$ & $0.242 \pm 0.11$ & $300.38 \pm 266.52$ & $109.57 \pm 70.69$ & $146.50 \pm 141.33$ & $154.85 \pm 134.47$ & \\
\hline \multicolumn{7}{|c|}{ Difference of plasma iron concentration $(\mu \mathrm{g} / \mathrm{mL})$, before and after therapy } \\
\hline Fe plasma & $+1.22 \pm 0.57$ & $-15.08 \pm 14.78$ & $\begin{array}{l}-261.92 \pm 183.20 \\
\#(P=0.000) \\
*(P=0.000)\end{array}$ & $\begin{array}{l}-217.08 \pm 198.79 \\
\#(P=0.000) \\
*(P=0.001)\end{array}$ & $\begin{array}{l}-168.20 \pm 166.24 \\
\#(P=0.000) \\
*(P=0.003)\end{array}$ & $\begin{array}{l}\text { "significant to C group, } \\
\text { *significant to } 10 \text { group }\end{array}$ \\
\hline \multicolumn{7}{|c|}{ Iron excretion via urine $[\mu \mathrm{g} \mathrm{Fe} / \mathrm{mL}$ urine] } \\
\hline $\begin{array}{l}\text { After } 3 \text { weeks = before } \\
\text { therapy }\end{array}$ & $0.01 \pm 0.00$ & $2.87 \pm 0.66$ & $2.23 \pm 0.71$ & $3.15 \pm 0.80$ & $4.19 \pm 1.84$ & \\
\hline $\begin{array}{l}\text { After } 4 \text { weeks = after } \\
\text { therapy }\end{array}$ & $0.01 \pm 0.00$ & $5.70 \pm 1.26$ & $41.50 \pm 6.67$ & $15.46 \pm 5.10$ & $8.18 \pm 1.94$ & \\
\hline \multicolumn{6}{|c|}{ Difference of iron excretion via urine $[\mathrm{ug} / \mathrm{mL}]$, before and after therapy } & $\begin{array}{l}\text { \# significant to C group, } \\
\text { * significant to } \mathrm{IO} \text { group }\end{array}$ \\
\hline Fe in urine & $0.00 \pm 0.00$ & $+2.83 \pm 1.64$ & $\begin{array}{l}+39.27 \pm 6.71 \\
\#(P=0.000) \\
*(P=0.000)\end{array}$ & $\begin{array}{l}+12.30 \pm 5.48 \\
\#(P=0.000) \\
*(P=0.000) \\
* *(P=0.000)\end{array}$ & $\begin{array}{l}+3.99 \pm 1.93 \\
\#(P=0.000) \\
* *(P=0.000) \\
* * *(P=0.000)\end{array}$ & $\begin{array}{l}* * \text { significant to IO+DFP } \\
\text { group } \\
* * * \text { significant to IO+M } \\
\text { group }\end{array}$ \\
\hline \multicolumn{7}{|c|}{$\%$ Inhibition epinephrine oxidation in plasma = SOD activity $[\mathrm{U} / \mathrm{mL}]$} \\
\hline After 4 weeks & $1.49 \pm 0.24$ & 0 & $0.81 \pm 0.24$ & $1.29 \pm 0.30$ & $1.47 \pm 0.34$ & Not significant \\
\hline
\end{tabular}

Note: $\mathrm{N}=$ normal control; IO= iron overload $90 \mathrm{mg} \mathrm{IP/} \mathrm{kg} \mathrm{BW} \mathrm{(negative} \mathrm{control);} \mathrm{IO+DFP} \mathrm{=} \mathrm{iron} \mathrm{overload} \mathrm{+} \mathrm{deferiprone} 75 \mathrm{mg} / \mathrm{kg}$ BW (positive control); $\mathrm{IO}+\mathrm{M}=$ iron overload + mangiferin $75 \mathrm{mg} / \mathrm{kg} \mathrm{BW}$; IO+EMF = iron overload + Mangifera foetida leaf extract $2930 \mathrm{mg} / \mathrm{kg}$ BWequivalent to mangiferin 75 $\mathrm{mg} / \mathrm{kg} \mathrm{BW}$.

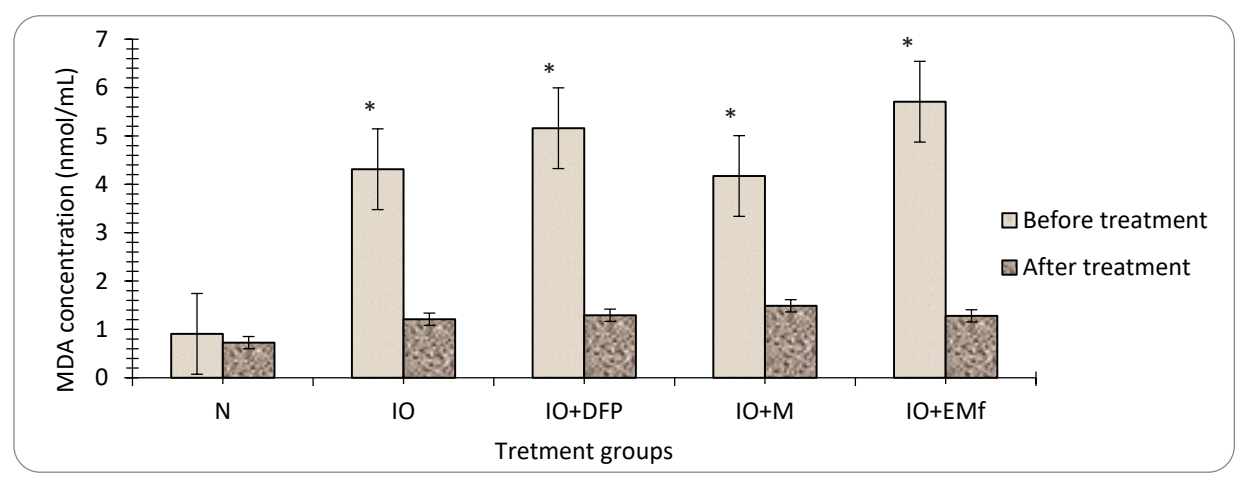

Figure 1. Mean of malondialdehyde (MDA) concentration among groups before and after treatment with error bars SD, $P=0.327$ Note: $\mathrm{N}=$ normal control, $\mathrm{IO}=$ iron overload, no treatment as negative control, IO+DFP = iron overload + treatment deferiprone $75 \mathrm{mg} / \mathrm{kg}$ BW as positive control, $\mathrm{IO}+\mathrm{M}=$ iron overload + mangiferin $75 \mathrm{mg} / \mathrm{kg} \mathrm{BW}, \mathrm{IO}+\mathrm{EMf}=$ iron overload + Mangifera foetida leaf water extract. ${ }^{*} P<0.05$ compare to $\mathrm{N}$ group .

arbitrary units (Figure 2). Mangiferin and the extract from mango leaves exert higher SOD-like activities than DFP.

\section{Discussion}

Until now, thalassemia is incurable. Management is a supportive therapy for patients with transfusion of blood on a regular basis to maintain hemoglobin levels of about 9-10 g/dL. However, regular blood transfusions in these patients increase endogenous iron levels. Currently, the average age of patients with thalassemia major can reach 3 decades, and generally patients die from an excess of iron in the myocardium (5).

To overcome the accumulation of excess iron (iron overload) iron chelating agents are administered to excrete excess iron from the body and to slow down the accumulation of Fe in tissues $(11,12)$. We used DFP as positive control, because it can be administered orally, i.e., via the same route as mangiferin or EMF. Iron chelation therapy must be given lifelong. Unfortunately, the drugs available in the market are still imported, so the costs 


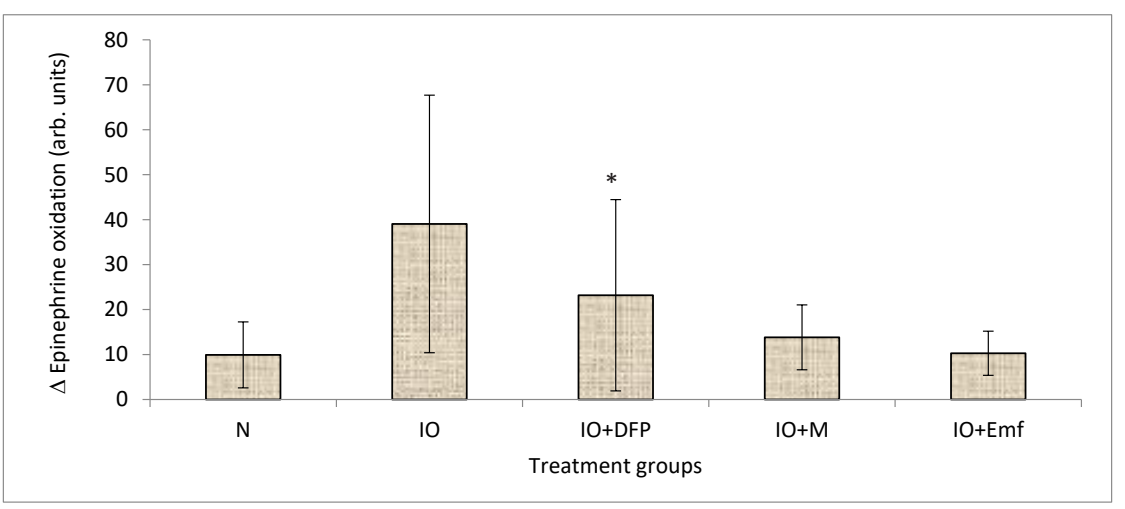

Figure 2. Epinephrine oxidation in blood.

$\mathrm{N}=$ normal control, $\mathrm{IO}=$ iron overload, no treatment as negative control, IO+DFP = iron overload + treatment deferiprone $75 \mathrm{mg} / \mathrm{kg}$ BW as positive control, IO+M = iron overload + mangiferin $75 \mathrm{mg} / \mathrm{kg} \mathrm{BW}, \mathrm{IO}+\mathrm{EMf}=$ iron overload + Mangifera foetida leaf extract, ${ }^{*} P<0.05 \mathrm{compare}$ to $\mathrm{IO}$ group

are very high. This is a burden for the patients and their families and for the government. Seeing these problems, we need to consider alternative drugs derived from domestic sources. Mangiferin is a polyphenolic antioxidant that has been found in and extracted from M. indica L.

This study showed that intraperitoneal administration of iron twice a week for 3 weeks with total amount of 90 mg iron increased plasma iron levels more than 200-fold as compared to controls and could serve as an animal model for iron overload. This method was developed from Papanastasiou et al (25). Intraperitoneal administration was chosen because it was easier and increased iron levels faster than oral administration.

After 3 weeks of excessive iron administration, it showed that DFP administration for 7 days could decrease plasma iron level by $70 \%$, while administration of mangiferin and Mangifera foetida extract could decrease plasma iron level by $60 \%$ and $50 \%$, respectively. The results showed that mangiferin could reduce plasma iron levels even though not as much as DFP. It proves that mangiferin has an ironchelating effect and can excrete iron from the body. This result corresponds to in vitro studies by Andreau et al (15), which proved that mangiferin could bind free iron. The administration of Mangifera foetida leaf extract also showed similar effect, because it contains mangiferin. The decrease in iron plasma levels in the therapy groups is proportional to the increase in iron excretion in the urine. In this study, the levels of Fe in urine in the fourth week was about 15-fold in the positive control (IO+DFP), about five-fold in the $\mathrm{IO}+$ mangiferin group, and two-fold in the IO+EMF group. In other words, mangiferin and the extract from Mango leaves increased iron excretion via urine, but not as strong as DFP.

In vitro tests with mangiferin have proven activity as iron chelator and as antioxidant, which was considered "SOD-like" activity $(26,27)$. This latter activity is not generally seen with iron chelators, especially not with deferoxamin or DFP. Pardo-Andreau et al $(28,29)$ have proven that mangiferin can form complexes with $\mathrm{Fe}$
(III). Such complexes can prevent the formation of and scavenge free radicals, thereby enhancing the effectiveness of mangiferin as antioxidant $(28,29)$.

In its antioxidant capacity, EMF was even more potent than purified mangiferin. This is certainly due to additional antioxidants contained in the EMF (30).

After 3 weeks, iron overload increased MDA significantly 4- to 5-fold. Treatment with iron-chelators decreased MDA generation, but the IO group without any therapeutic treatment exhibited the same effect. Thus, there are no differences between the ironoverloaded groups. In other words, in the fourth week, lipid peroxidation decreased, because administration of excessive iron was discontinued, no matter whether rats obtained iron chelators or not.

SOD activity in plasma was measured as inhibition of epinephrine oxidation. It has been discussed in literature and questioned whether this assay is suitable for determination in biological systems. The strongest antioxidant effect was observed with the Mango leaves extract, even slightly higher than by mangiferin alone. This may be due to other antioxidant components in the leaf extract, which contribute to the total antioxidant activity.

\section{Conclusion}

From the experiments with iron-overloaded rats we conclude that mangiferin and mangiferin-containing extracts from $M$. foetida leaves (EMF) are potent candidates as antioxidant iron chelators in the management of ironoverloaded thalassemia patients.

Further investigations are necessary to assay the pharmacokinetics of mangiferin with varying dosage and pharmaceutical preparation procedures, before we can recommend mangiferin to humans.

\section{Authors' contributions}

$\mathrm{AE}$ and TW contributed equally to laboratory experiments and data collection. PAW was involved 
in data collection and responsible for the relevance of the animal experiments for thalassemia patients. EHP was involved in data collection and data management. HJF made the concept of the study, supervised the experiments and wrote the manuscript.

\section{Conflict of interests}

None.

\section{Ethical considerations}

The study was approved by the Health Research Ethics Committee of the Faculty of Medicine, Universitas Indonesia $\quad(\# 205 / \mathrm{H} 2 . \mathrm{F} 1 / \mathrm{ETIK} / 2013)$

\section{Funding/Support}

This research was funded by Directorate of Research and Community Service (DRPM), Universitas Indonesia Hibah Riset Madya and PITTA 2018.

\section{References}

1. Rund D, Rachmilewitz E. $\beta$-thalassemia. N Eng J Med. 2005;353(11): 1135-45.

2. Wahidiyat I, Wahidiyat PA. Genetic problems at present and their challenges in the future: Thalassemia as a model. Presented at: Kongres Nasional Ilmu Kesehatan Anak XIII; Bandung; 4-7 July 2005.

3. Aji DN, Silman C, Aryudi C, Centauri C, Andalia D, Astari D. The factors related to the quality of life of thalassemia major patients in the Thalassemia Center Paediatric Department RSCM. Sari Pediatri. 2009;11(2):85-9

4. Andriastuti M, Sari TT, Wahidiyat PA, Putriasih SA. The blood transfusions need in post splenoctomy thalassemia major patients. Sari Pediatri. 2011;13(4): 244-9

5. Fleming RE, Ponka P. Iron overload in human disease. N Engl J Med. 2012; 366:348-59

6. Byrns MC, Penning TM. Environmental toxicology: Carcinogens and heavy metals. In: Brunton LL, Chabner BA, Knollmann BC, edis. The pharmacological basis of therapeutics. New York: McGraw Hill; 2011. p. 1875-6

7. Wiria MSS. The Heavy Metals and Antagonist. In: Setiabudy R, Gan S, eds. Farmakologi dan Terapi. Jakarta: Balai Penerbit UI; 2011. p. 860-1

8. Lee R, Bithell TC, Foerster J, Athens JW, Lukens JN. Wintrobe's Clinical Hematology: The Thalassemias and Related Disorders. 9th ed. Philadelphia: Lea \& Febiger; 1993. p. 1131.

9. Laksmitawati DR, Handayani S, Udyaningsih-Freisleben $\mathrm{SK}$, et al. Iron status and oxidative stress in $ß$-thalassemia patients in Jakarta. BioFactors. 2003; 19:53-62

10. Udyaningsih-Freisleben SK, Kurniati V, Prasetyo PB, Handayani S, Adhiyanto C, Soegianto RR. Isolated erythrocyte membranes of transfusion-dependent and nontransfused thalassemia patients in Jakarta - investigated by electron paramagnetic resonance spectroscopy. BioFactors. 2003;19:87-100

11. Brittenham GM. Iron-chelating therapy for transfusional iron overload. N Engl J Med. 2011;364(2):146-56. doi:
10.1056/NEJMc1101838.

12. Farmaki K, Tzoumari I, Pappa C. Oral chelators in transfusion-dependent thalassemia major patients may prevent or reverse iron overload complications. Blood Cells Mol Dis. 2011;47(1):33-40. doi: 10.1016/j. bcmd.2011.03.007.

13. Maskoen AM, Safitri R, Milanda T, Reniarti L, Fauziah PN. Iron chelation ability of granule Sappan wood (Caesalpinia sappan, L.) extract on iron-overloaded. International Journal of PharmTech Research. 9(5):299-305

14. Pardo-Andreau E. Iron complexing activity of mangiferin. Eur J Pharmacol. 2005;513:47-55.

15. Pardo-Andreau GL, Sanchez-Baldoquin C, Avila-Gonzalez R, Yamamoto ETS, Revilla A, Uyemura SA. Interaction of vimang (Mangifera indica L. extract) with Fe(III) improves its antioxidant and cytoprotecting activity. Pharmacol Res. 2006;54: 389-95.

16. Pardo-Andreau GL, Barrios MF, Curti C, Hernandez I, Merino N, Lemus Y. Protective effects of Mangifera indica L extract (Vimang), and its major component mangiferin, on iron induced oxidative damage to rat serum and liver. Pharmacol Res. 2008;57:79-86.

17. Rodriguez J, Di Pierro D, GKBia M, Monaco S, Delgado R, Coletta M. Effects of natural extract from Mangifera indica $\mathrm{L}$, and its active compound, mangiferin, on energy state and lipid peroxidation of red blood cells. Biochim Biophys Acta. 2006;1760:1333-42. Doi: 10.1016/j.bbagen.2006.04.005.

18. Soediro S, Iwang S, Kosasih P, Asep W. Isolation and characterization of mangiferin from mango leaves and the ratio of from seven cultivars Mangifera indica. Acta Pharm Indones. 1991; 4 (16), 26-35.

19. Purwaningsih, EH, Hanani E, Amalia P, Krisnamurti DG. The chelating effect of Mangifera foetida water extract on serum thalassaemic patient. J Indones Med Assoc. 2011; 61(8):321-5.

20. Wahyuni T, Sari SP, Estuningtyas A, Freisleben HJ. The toxicity of Mangifera foetida L. leaf extract as an Iron chelator in terms of LD50 and to the blood cell components. Pharm Sci Res. 2016; 2(3):124-34. (Indonesian).

21. Papanastasiou DA, Vayenas D V, Vassilopoulos A, Repanti M. Animal and in vitro models in human disease concentration of iron and distribution of iron and transferrin after experimental iron overload in rat tissues in vivo: Study of the liver, the spleen, the central nervous system and other organs. Pathol Res Pract. 2000;196(1):4754

22. Misra HP, Fridovich I. The role of superoxide anion in the autoxidation of epinephrine and a simple assay for superoxide dismutase. J Biol Chem. 1972;247:3170-5.

23. Devasagayam TPA, Boloor KK, Ramasarma T. Methods for estimating lipid peroxidation: An analysis of merits and demerits. Indian J Biochem Biophys. 2003; 40:300-8

24. Dahlan MS. Statistik untuk Kedokteran dan Kesehatan. 5th ed. Jakarta: Salemba Medika; 2011.

25. Papanastasiou DA, Vayenas DV, Vassilopoulos A, Repanti M. Animal and in vitro models in human disease concentration of iron and distribution of iron and transferrin after experimental iron overload in rat tissues in vivo: Study of the liver, the spleen, the central nervous 
system and other organs. Pathol Res Pract. 2000;196(1):4754.

26. Leiro JM, Alvarez E, Arranz JA, Siso IG, Orallo F. In vitro effects of mangiferin on superoxide concentrations and expression of the inducible nitric oxide synthase, tumour necrosis factor- $\alpha$ and transforming growth factor $\beta$-genes. Biochem Pharmacol. 2003;65:1361-71.

27. Leopoldini M, Russo N, Toscano M. The molecular basis of working mechanism of natural polyphenolic antioxidants. Food Chem. 2011;125:288-306.

28. Pardo-Andreau GL, Baldoquin CS, Gonzales RA, Delgado
R, Naal Z, Curti C. Fe(III) improves antioxidant and cytoprotecting activities of mangiferin. Eur J Pharmacol. 2006;547(1-3):31-6. doi: 10.1016/j.ejphar.2006.07.040.

29. Pardo-Andreau GL, Cavalheiro RA, Dorta DJ, Naal Z, Delgado R, Vercesi AE. Fe(III) shifts the mitochondria permeability transition-eliciting capacity of mangiferin to protection of organelle. J Pharmacol Exp Ther. 2007;320(2):646-53. doi: 10.1124/jpet.106.112003.

30. Deng W, Fang X, Wu J. Flavonoids function as antioxidant: By scavenging reactive oxygen species or by chelating iron. Radias Phys Chem. 1997;50(3):271-6 